\title{
The Immunomodulatory Effect of Cinnamon (Cinnamomum Burmanii) bark extract on the C-Reactive Protein (CRP) Level, Leukocyte Count and Leukocyte Type Count of Wistar Rats Exposed to Staphylococcus Aureus
}

\author{
Astika Widy Utomo ${ }^{1 *}$, Dwi Retnoningrum ${ }^{2}$, Ainun Rahmasari Gumay ${ }^{3}$ \\ ${ }^{1}$ Department of Pharmacology and Therapy, Faculty of Medicine, Diponegoro University \\ ${ }^{2}$ Department of Clinical Pathology, Faculty of Medicine, Diponegoro University \\ ${ }^{3}$ Department of Physiology, Faculty of Medicine, Diponegoro University \\ *Corresponding author. Address: Department of Pharmacology and Therapy, Faculty of Medicine, Diponegoro University, \\ Jalan Prof. H. Soedarto, SH Tembalang Semarang, Phone: 085641390824, Email: astikautomo@gmail.com
}

\begin{abstract}
Introduction: Bacterial infection induces inflammation in human body. This process produces humoral and cellular immune responses. Cinnamomum burmanii grows very vast in Indonesia and contains cinnamaldehyde known to have an anti-inflammatory effect. Objective: To prove the effect of $C$. burmanii bark extract on CRP level, leukocyte count and differential blood count.

Methods: A posttest-only controlled group design with 25 Wistar Rats divided into 5 groups was employed. The CN-G group was given the standard feed, the CP-G group was given the standard feed and levamisole $2.5 \mathrm{mg} / \mathrm{KgBW}$, while the CBE-100, CBE-200, and CBE-400 groups were respectively given the standard feed and cinnamon bark extract $100 \mathrm{mg} / \mathrm{kgBW}, 200 \mathrm{mg} / \mathrm{KgBW}$ and $400 \mathrm{mg} / \mathrm{KgBW}$. The treatments were conducted for 7 consecutive days. On day 8, all rats were injected with the suspense of $S$. aureus intraperitoneally. The blood was then drawn on day 9, followed with CRP level measurement using the ELISA method. The total leukocyte count and differential blood count were manually measured.

Results: There is no significant difference in the value of CRP level (One Way ANOVA; $p=0.749$ ) with the total counts of leukocytes ( $p=0.685$ ), monocytes $(p=0.769)$, and eosinophil $(p=0.123)$ between groups. The neutrophils and lymphocytes of CBE-100 group are significantly different from the other groups.

Conclusion: C. burmanii extract has a potential benefit as immunomodulator.
\end{abstract}

Keywords: Cinnamomun burmanii, CRP, leukocytes, differential blood counts, Staphylococcus aureus

\begin{abstract}
ABSTRAK
Latar Belakang: Proses inflamasi akibat infeksi bakteri oleh tubuh akan membangkitkan respon imun humoral dan seluler. Kayu manis spesies Cinnamomum burmanii merupakan spesies kayu manis yang banyak tumbuh di Indonesia. Salah satu kandungannya yaitu Cynnamaldehyde diketahui mempunyai efek antiinflamasi.

Tujuan: Membuktikan efek ekstrak kulit batang C. burmanii terhadap kadar C-Reactive Protein (CRP), jumlah leukosit, dan hitung jenis leukosit.

Metode: Penelitian dengan post test only controlled group design menggunakan 25 ekor tikus Wistar jantan yang dibagi secara acak menjadi 5 kelompok. Kelompok CN-G diberi pakan standar, kelompok CP-G diberi pakan standard dan levamisole 2,5 mg/kgBB, kelompok CBE-100, CBE-200, CBE-400 diberi pakan standard dan ekstrak kayu manis berturut-turut sebanyak $100 \mathrm{mg} / \mathrm{kgBB}, 200 \mathrm{mg} / \mathrm{kgBB}$, dan $400 \mathrm{mg} / \mathrm{kgBB}$. Perlakuan diberikan selama 7 hari dan pada hari ke-8 tikus diinjeksi suspensi $S$. aureus secara intraperitoneal. Pengambilan sampel darah dilakukan pada hari ke-9. Pemeriksaan kadar CRP dilakukan dengan metode ELISA, jumlah dan hitung jenis leukosit dihitung secara manual.

Hasil: Hasil uji One Way ANOVA menunjukkan tidak ada beda bermakna kadar CRP ( $\mathrm{p}=0,749)$, jumlah leukosit ( $\mathrm{p}=0,685$ ), hitung jenis monosit $(\mathrm{p}=0,769)$ dan hitung jenis Eosinophil (uji Kruskal Wallis; $\mathrm{p}=0,123)$. Pada hitung jenis netrofil dan limfosit ditemukan beda bermakna pada kelompok CBE-100 dibandingkan kelompok lainnya $(\mathrm{p}<0,00)$

Kesimpulan: Ekstrak kulit batang kayu manis C. Burmanii mempunyai potensi sebagai immunomodulator.
\end{abstract}

Kata Kunci: Cinnamomum burmanii, CRP, jumlah leukosit, hitung jenis leukosit, Staphylococcus aureus

\section{INTRODUCTION}

Staphylococcus aureus (S. aureus) is commensal bacteria which may be found in $30 \%$ of human population. Simultaneously, S. aureus is human's main pathogen which causes infection in various organs, such as bacteremia, infective endocarditis, osteoarticular

Copyright @ 2020 Authors. This is an open access article distributed under the terms of the Creative Commons Attribution-NonCommercialShareAlike 4.0 International License (http://creativecommons.org/licenses/by-nc-sa/4.0/), which permits unrestricted non-commercial use, distribution, and reproduction in any medium, provided the original author and source are properly cited. 
Utomo, et al.

infection, skin and soft tissue, respiratory tract, and infection in users of invasive devices (Tong et al., 2015). Emerging strain which is resistant to antibiotic such as Methicillin-Resistant S. aureus (MRSA) makes it difficult to eradicate infectious diseases in Indonesia.

Bacterial infection in the body will be initiated with an inflammatory mechanism. Inflammation is a biological response to a tissue injury. Inflammatory process increases the permeability of blood vessel wall, which is followed with immune cell migration and increased activity of signaling proteins and enzymes (Liao et al., 2012). Tissue macrophages, monocytes, mastocytes, platelet and endothelial cells may produce proinflammatory cytokines as a response to inflammation. Interleukin-1 (IL 1), interleukin 6 (IL 6) and Tumor Necrosis Factor (TNF) alpha are cytokines released by macrophages and initiate an acute phase immune response. In this acute phase immune reaction, liver synthesizes a protein called CReactive Protein (CRP). CRP is an acute phase protein of which value may increase 1000 times at the site of inflammation or infection. CRP has long been used as a laboratory sign of infection (Kingsley and Jones, 2008; Sproston and Ashworth, 2018). CRP is capable of recognizing self-molecule and foreign molecule based on pattern recognition. The bond between CRP and phosphocholine on bacterial cell membrane will activate complement through the classical pathway (Sproston and Ashworth, 2018).

Cellular immune response is mediated by $\mathrm{T}$ lymphocyte (T cell). CD4+ plays an important role in cellular and humoral immune system. Naïve $T$ cell will recognize antigen and be active in peripheral lymphoid organs which will be differentiated to effector T cells and memory cells. With this activation, it will form sufficient antibody response which will in turn activate neutrophil and macrophage, which are useful in defense against S. aureus infection (Yu et al., 2018). Blood cell type count illustrates the relative percentage of respective type of white blood cells.

Cinnamon (Cinnamomum sp.) is of the Lauraceae family covering 54 species. The most important Cinnamomum species are C. burmanii, C. zeylanicum and C. cassia. C. burmanii (Java cinnamon) is an indiginous species to Indonesia, vastly cultivated and an important commodity in trade. Its dry bark has long been used as food spice and coloring (P. Chen et al., 2014). Ranasinghe, et al. (2013) presents a comprehensive review of cinnamon's medical benefit, such as anti-bacteria and anti-parasite, reducing blood sugar and cholesterol, antioxidant, anti-nociception, antiinflammation and so on (Ranasinghe et al., 2013). http://jurnal.unissula.ac.id/index.php/sainsmedika

The main components of C. burmanii bark essential oil are trans-cynanmaldehyde (60.72\%), eugenol (17,62\%) and coumarin (13,39\%) (Faishal et al., 2017). Cynnamaldehyde is a component with antibacterial and anti-inflammatory effect as its main role (Liao et al., 2012). In vitro, cynnamaldehyde inhibits monocyte adhesion and inhibits IL- $1 \beta$ and TNF- $\alpha$ secretion stimulated by lipopolysaccharide (LPS) as well as suppresses NF-KB expression with Helicobacter pylori infected rats (Chao et al., 2008; Liao et al., 2008; Muhammad et al., 2015). The effect of cinnamon extract on S. aureus infected Wistar rat's immune system is not clearly known, thus this research is expected to give new information of the benefit of cinnamon for inflammatory process.

\section{METHODS}

This experimental research employs a posttestonly control group design. The research subjects were 25 male Wistar rats which are randomly divided into 5 groups. The groups were $\mathrm{CN}-\mathrm{G}$ group given with the standard feed, CP-G group given with standard feed and levamisole $2.5 \mathrm{mg} / \mathrm{kgBW}, \mathrm{CBE}-100$ group given with standard feed and cinnamon extract 100 $\mathrm{mg} / \mathrm{kgBW}, \mathrm{CBE}-200$ group given with standard feed and cinnamon extract $200 \mathrm{mg} / \mathrm{kgBW}$ and CBE-400 group given with standard feed and cinnamon extract $400 \mathrm{mg} / \mathrm{kgBW}$. The treatments were performed for 7 consecutive days and on day 8 the rats were injected with S. aureus suspension intraperitoneally. The blood was sampled $2 \mathrm{~mL}$ on day 9 through the rats' lateral tail vein for CRP level examination. This research was conducted upon approval from the Health Research Ethics Commission (KEPK) of the Faculty of Medicine of Diponegoro University/RSUP Dr. Kariadi Semarang under number: 922/EC/FK-RSDK/IX/2016 issued on September 19, 2016.

\section{C. burmannii bark extraction}

C. burmanii bark was extracted using the sokletation extraction method with ethanol $70 \%$ as solvent. The final result of extract was obtained in the form of powder.

\section{Staphylococcus aureus injection}

S. aureus was cultured in blood agar media, then 1-2 colonies were taken for suspension into $2 \mathrm{~mL} \mathrm{NaCl}$ $0.9 \%$ until turbidity pursuant to the standard $0.5 \mathrm{Mac}$ Farland. The suspension was then injected into the rats intraperitoneally at a concentration of 108 for $0.2 \mathrm{~mL}$. 
http://jurnal.unissula.ac.id/index.php/sainsmedika

The Immunomodulatory Effect of Cinnamon (Cinnamomum Burmanii) bark extract on the C-Reactive Protein (CRP)...

Table 1. Mean of CRP Level, Leukocyte Count and Leukocyte Type Count

\begin{tabular}{|c|c|c|c|c|c|c|}
\hline Variable & $\begin{array}{c}\text { CN-G } \\
N=5 \\
\text { Mean } \pm \text { SD }\end{array}$ & $\begin{array}{c}\text { CP-G } \\
\text { N=5 } \\
\text { Mean } \pm \text { SD }\end{array}$ & $\begin{array}{c}\text { CBE-100 } \\
N=5 \\
\text { Mean } \pm \text { SD }\end{array}$ & $\begin{array}{c}\text { CBE-200 } \\
N=5 \\
\text { Mean } \pm \text { SD }\end{array}$ & $\begin{array}{c}\text { CBE-400 } \\
\text { N=5 } \\
\text { Mean } \pm \text { SD }\end{array}$ & $P$ value \\
\hline CRP Level (mg/dL) & $0.81 \pm 0.45$ & $0.84 \pm 0.36$ & $0.70 \pm 0.15$ & $1.00 \pm 0.53$ & $0.77 \pm 0.38$ & $\begin{array}{l}>0.05^{*} \\
0.09^{* *} \\
0.75^{* * *}\end{array}$ \\
\hline $\begin{array}{l}\text { Number of leukocyte } \\
(\Sigma)\end{array}$ & $\begin{array}{l}11203 \\
\pm 2376.50\end{array}$ & $\begin{array}{l}13410 \\
\pm 3207.10\end{array}$ & $\begin{array}{l}13460 \\
\pm 8060.66\end{array}$ & $\begin{array}{l}9070 \\
\pm 6267.73\end{array}$ & $\begin{array}{l}11798 \\
\pm 5007.19\end{array}$ & $\begin{array}{l}>0.05^{*} \\
0.08^{* *} \\
0.69^{* * *}\end{array}$ \\
\hline Neutrophil & $18.40 \pm 7.33$ & $22.20 \pm 2.86$ & $33.60 \pm 9.32$ & $19.40 \pm 2.60$ & $18.20 \pm 3.11$ & $\begin{array}{l}>0.05^{*} \\
0.11^{* *} \\
0.01^{\prime \prime}\end{array}$ \\
\hline Lymphocyte & $71.60 \pm 3.36$ & $70 \pm 4.42$ & $59 \pm 6.89$ & $74.20 \pm 4.44$ & $74.20 \pm 3.49$ & $\begin{array}{l}0.00^{*} \\
>0.05^{* *} \\
0.21^{* * *}\end{array}$ \\
\hline Monocyte & $7.40 \pm 2.30$ & $6 \pm 1.58$ & $5.40 \pm 3.65$ & $6.60 \pm 2.30$ & $7 \pm 2.92$ & $\begin{array}{l}>0.05^{*} \\
0.26^{* *} \\
0.8^{* * *}\end{array}$ \\
\hline Eosinophil & $2.60 \pm 2.07$ & $1.80 \pm 1.10$ & $2 \pm 0.71$ & $1.40 \pm 1.52$ & $0.40 \pm 0.55$ & $\begin{array}{l}>0.05^{*} \\
0.08^{* * *} \\
0.12^{\prime \prime}\end{array}$ \\
\hline
\end{tabular}

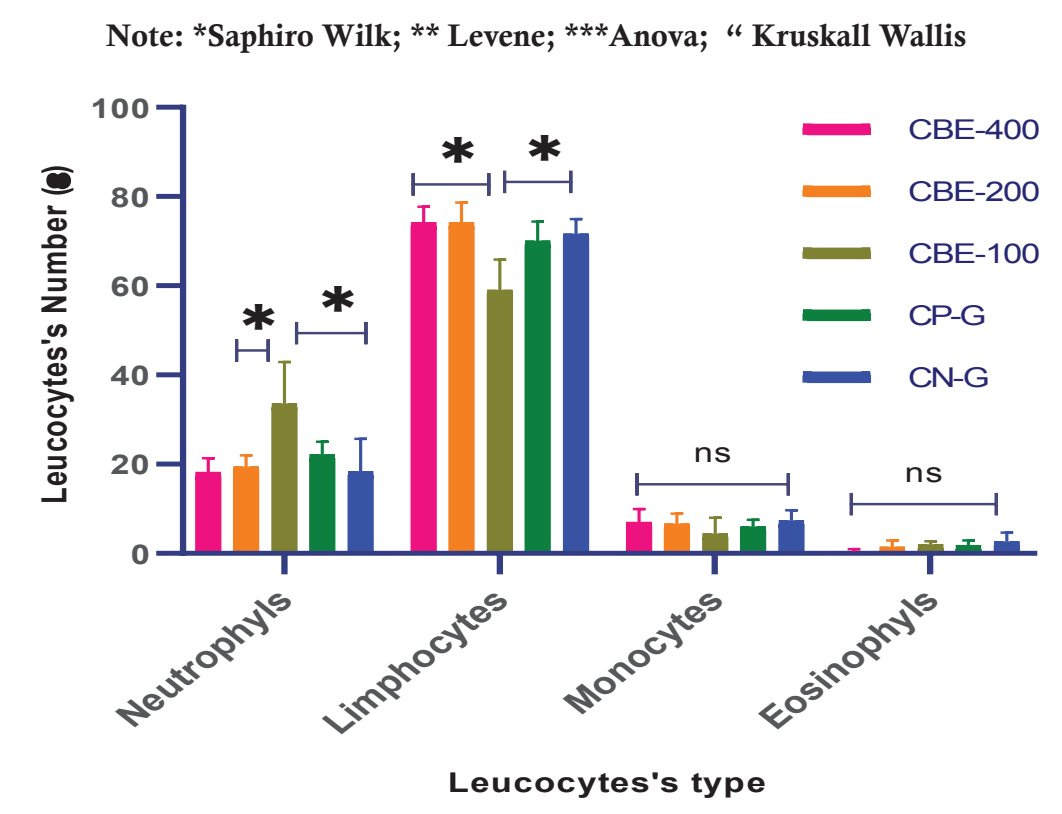

Figure 1. Leucocyte count in each group. Mann Withney Analysis: * $\mathbf{p}<0.05$; ns not significant

\section{CRP level examination}

CRP level was examined using the ELISA method at a wavelength of $450 \mathrm{~nm}$ at the GAKI Laboratory, Faculty of Medicine, Diponegoro University, Semarang.

\section{Leukocyte count and Leukocyte type count}

Leukocyte count and leukocyte type count were examined manually on blood sample using Neubauer Hemocytometer counting chamber by two examiners. Blood sample was dissolved in Turk's solution and counted per 4 large fields of view. A kappa test was conducted to reduce subjectivity bias, resulting in $p>0.8$. Blood film was used to determine the type of leukocyte and colored using Hematoxylin-Eosin staining.

\section{Data analysis}

The data were presented in mean and standard deviation (SD). The data resulted were tested for data normality and homogeneity. The data of CRP level, leukocyte count, and lymphocyte and monocyte type count are normally distributed with homogenous variance, a one way ANOVA was then conducted with a post hoc test. The data of neutrophil and eosinophil type 
Utomo, et al.

counts are not normally distributed, a Kruskal-Wallis non-parametric test was then conducted, followed with a Mann-Whitney test. The result was deemed significant if $\mathrm{p}$ value $<0.05$.

\section{RESULTS}

After C. burmanii extract treatment and injection with S. aureus, the mean of CRP level, leukocyte count and leukocyte type count were displayed in Table 1.

CN-G: Control Negative-Group; CP-G: Control Positive-Group; CBE-100: group administered with $100 \mathrm{mg} / \mathrm{kgBB}$ Cinnamomum burmanii; CBE-200: group administered with $200 \mathrm{mg} / \mathrm{kgBB}$ Cinnamomum burmanii CBE-400: group administered with $400 \mathrm{mg} /$ kgBB Cinnamomum burmani

Table 1 shows that statistically, the CRP level, leukocyte count, monocyte count and eosinophil type count are not significantly different between the treated groups $(p>0.05)$. Meanwhile, the neutrophil and lymphocyte counts show significant difference between the groups $(p<0.05)$. To identify which groups are significantly different, an LSD post hoc test was conducted for lymphocyte type count data and a Mann Whitney test was conducted for neutrophil type count data.

\section{Neutrophil type count}

The neutrophil type count of CBE-100 groups is of the highest value. Statistically, using the Mann Whitney test, the lymphocyte type count of CBE-100 group is significantly different from that of $\mathrm{CN}-\mathrm{G}$ group $(p=0.01)$ and of CBE-200 group $(p=0.02)$ (figure 1).

\section{Lymphocyte type count}

The mean lymphocyte type count of CBE-100 group in Table 1 seems to be of the lowest value among the groups. Statistically, according to the data of LSD post hoc test, the lymphocyte type count of CBE-100 group is significantly different from that of $\mathrm{CNG}, \mathrm{CPG}$, CBE-200 and CBE-400 groups $(p<0.00)$ (figure 1).

\section{DISCUSSION}

Immune system is a very complex defense mechanism requiring cooperation between immune system, nervous system and endocrine. Its main function is to protect the body from external biological invasion and to regulate body's internal environment. The imunomodulatory concept shows the non-specific work of a substance on the immune system (cellular or effector molecule production by activated cells) (Balekar et al., 2014).

Imunomodulator works in various elements of the immune system through various mechanisms. In this research, we find that $\mathrm{CBE}$ administration does not significantly influence humoral immune system (CRP), but indirectly influences the composition of cellular immune system (neutrophil and lymphocyte type counts) in pathogen infection (S. aureus injection).

C-Reactive Protein (CRP) is an acute phase protein which significantly increases in an inflammatory process. In the statistical analysis, we find that there is no significant difference in the CRP level between the research groups, but the CRP level of CBE-100 and CBE-400 groups is generally lower than that of CNG group, proving that CBE influences the CRP level decrease. The meta analysis study conducted by Vallianou et al. shows that administration of $C$. burmanii extract and its derivatives may decrease CRP level (Vallianou et al., 2019).

CRP is excreted in 4-6 hours after stimulus, and will be multiplied every 8 hours thereafter and reach its peak level in 36-50 hours. As an inflammatory sign, CRP plays a role in non-specific immunity which may with assistance of $\mathrm{Ca} 2+$ bind various molecules, such as phosphorylcoline expressed on damaged cell surface and polysaccharides and peptosaccharides on bacteria, parasite and fungi. Cynnamaldehide in C. burmanii extract may inhibit IL-1 $\beta$ and $\mathrm{TNF} \alpha$ secretion in lipopolysaccharide (LPS), which influences CRP expression. This secretion inhibition is mediated by modulation via JNK pathway, p38, activation of

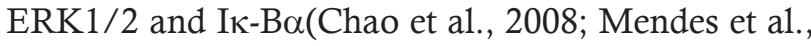
2016).

The administration of C. burmanii bark extract in this research does not influence total leukocyte count and monocyte and eosinophil type counts. There is significant different in neutrophil and lymphocyte type counts between CBE-100 group and other groups. Neutrophil is one type of leukocyte serving in innate immune system, particularly in phagocyte function. Lymphocyte is a subtype of leukocyte serving in adaptive immune system. Immune system modulation resulting from $\mathrm{C}$. burmanii bark extract administration influences immune response at the time of exposure to S. aureus infection (Nassan et al., 2015).

$\mathrm{T}$ cell is an important immune cell in adaptive immune system in improvement if phagocytosis mechanism and will through memory process provide long-term immunity. When Naïve T cells meet an antigen, they will become an active lymphoblast which will be proliferated and differentiated to be effector cells, which directly kill pathogen or secrete cytokines, such as IFN- $\gamma$, IL-2 and IL-4. IL-2 improves the lymphocyte resistance and growth factor, while IL- 
The Immunomodulatory Effect of Cinnamon (Cinnamomum Burmanii) bark extract on the C-Reactive Protein (CRP)...

4 induces antibody production. Cytokine modulation in administration of $\mathrm{C}$. burmanii and its derivative products may influence leukocyte count and leukocyte type count (Lee et al., 2011). The research conducted by Roth-Walter et al. in 2014 states that cinnamaldehyde at low concentration increases $\mathrm{NF}-\kappa \mathrm{B}$ and at high concentration shows otherwise. The anti-inflammatory effect of cinnamaldehyde which is mediated by NF$\kappa \mathrm{B}$ blockage inhibits cell viability and influences proliferation and apoptosis induction in immune cells (Roth-Walter et al., 2014).

This change in leukocyte population is associated with administration of $C$. burmanii bark extract which is induced by TNF- $\alpha$ through adhesion molecule expression (Liao et al., 2012). The research conducted by Mendes et al. in 2016 states that cinnamaldehyde, an important constituent in C. burmanii, activates Transient Receptor Potential Ankyrin 1 (TPRA1) to modulate leukocyte cells (Mendes et al., 2016). Besides influencing migration, C. burmanii extract may influence secretion of some cytokines serving in proliferation and leukocyte differentiation, such as Il2 and Il-4 (Lee et al., 2011). Chen et al. in 2014 states that procyanidin oligomer content in C. burmanii has the effect of suppressing splenocyte proliferation and also reducing interferon $\gamma$ (IFN $\gamma$ ) and IL-2 contents (L. Chen et al., 2014).

The interesting fact regarding C. burmanii extract is that immunomodulatory function is determined by its dose and species (Vetal et al., 2013). The difference in the content of different types of constituent causes C. burmanii bark extract to be immunostimulant and immunosuppressant (Balekar et al., 2014). This is apparent from the result of variable of the three treatment groups administered with $\mathrm{C}$. burmanii bark extract. In this result, we use C. burmanii extract and ethanol 70\% as solvent. Ethanol $70 \%$ or $96 \%$ renders maximum effect on cinnamaldehyde and trans-cinnamaldehyde contents. Different extraction method and solvent type choice influence the final content of active agent obtained during extraction process (Wardatun et al., 2017).

\section{CONCLUSION}

Cinnamon (C. burmanii) bark extract is a potential immunomodulator. Therefore, more extensive further research is needed to examine the main effect of Cinnamon (C. burmanii) bark extract on immune

system, particularly in the process of expression of genes and cytokines which play a role in cellular immune system proliferation process.

\section{CONFLICT OF INTEREST}

Authors declare no conflict of interest within this manuscript.

\section{REFERENCES}

Balekar, N., Bodhankar, S., Mohan, V., Thakurdesai, P.A., 2014. Modulatory activity of a polyphenolic fraction of Cinnamomum zeylanicum L. bark on multiple arms of immunity in normal and immunocompromised mice. J. Appl. Pharm. Sci. 4, 114-122. https://doi.org/10.7324/ JAPS.2014.40720

Chao, L.K., Hua, K.F., Hsu, H.Y., Cheng, S.S., Lin, I.F., Chen, C.J., Chen, S.T., Chang, S.T., 2008. Cinnamaldehyde inhibits pro-inflammatory cytokines secretion from monocytes/ macrophages through suppression of intracellular signaling. Food Chem. Toxicol. 46, 220-231. https://doi.org/10.1016/j.fct.2007.07.016

Chen, L., Yang, Y., Yuan, P., Yang, Y., Chen, K., Jia, Q., Li, Y., 2014. Immunosuppressive Effects of A-Type Procyanidin Oligomers from Cinnamomum tamala . Evidence-Based Complement. Altern. Med. 2014, 1-9. https:// doi.org/10.1155/2014/365258

Chen, P., Sun, J., Ford, P., 2014. Differentiation of the four major species of cinnamons (C. burmannii, C. verum, C. cassia, and C. loureiroi) using a flow injection mass spectrometric (FIMS) fingerprinting method. J. Agric. Food Chem. 62, 2516-2521. https://doi.org/10.1021/ jf405580c

Faishal, L.F., Utomo, A.W., Retnoningrum, D., 2017. Pengaruh Pemberian Ekstrak Kayu Manis (Cinnamomum Studi Eksperimental Pada Tikus Wistar Yang Dipapar. Pengaruh Pemberian Ekstrak Kayu Manis (Cinnamomum Stud. Eksp. Pada Tikus Wistar Yang Dipapar 6, 772-781.

Kingsley, A., Jones, V., 2008. Diagnosing wound infection: The use of C-reactive protein. Wounds UK 4, 32-46.

Lee, B.J., Kim, Y.J., Cho, D.H., Sohn, N.W., Kang, H., 2011. Immunomodulatory effect of water extract of cinnamon on anti-CD3-induced cytokine responses and p38, JNK, ERK1/2, and STAT4 activation. Immunopharmacol. Immunotoxicol. 33, 714-722. https://doi.org/10.3109/089239 73.2011 .564185

Liao, B.C., Hsieh, C.W., Liu, Y.C., Tzeng, T.T., Sun, Y.W., Wung, B.S., 2008. Cinnamaldehyde inhibits 
Utomo, et al.

the tumor necrosis factor- $\alpha$-induced expression of cell adhesion molecules in endothelial cells by suppressing NF- $\mathrm{NB}$ activation: Effects upon I $\mathrm{B}$ and Nrf2. Toxicol. Appl. Pharmacol. 229, 161-171. https://doi.org/10.1016/ j.taap.2008.01.021

Liao, J.-C., Deng, J.-S., Chiu, C.-S., Hou, W.-C., Huang, S.-S., Shie, P.-H., Huang, G.-J., 2012. AntiInflammatory Activities of Cinnamomum cassia Constituents In Vitro and In Vivo. EvidenceBased Complement. Altern. Med. 2012, 1-12. https://doi.org/10.1155/2012/429320

Mendes, S.J.F., Sousa, F.I.A.B., Pereira, D.M.S., Ferro, T.A.F., Pereira, I.C.P., Silva, B.L.R., Pinheiro, A.J.M.C.R., Mouchrek, A.Q.S., MonteiroNeto, V., Costa, S.K.P., Nascimento, J.L.M., Grisotto, M.A.G., da Costa, R., Fernandes, E.S., 2016. Cinnamaldehyde modulates LPS-induced systemic inflammatory response syndrome through TRPA1-dependent and independent mechanisms. Int. Immunopharmacol. 34, 6070. https://doi.org/https://doi.org/10.1016/ j.intimp.2016.02.012

Muhammad, J.S., Zaidi, S.F., Shaharyar, S., Refaat, A., Usmanghani, K., Saiki, I., Sugiyama, T., 2015. Anti-inflammatory Effect of Cinnamaldehyde in Helicobacter pylori Induced Gastric Inflammation. Biol. Pharm. Bull. 38, 109-115. https://doi.org/10.1248/bpb.b14-00609

Nassan, M.A., Mohamed, E.H., Abdelhafez, S., Ismail, T.A., 2015. Effect of clove and cinnamon extracts on experimental model of acute hematogenous pyelonephritis in albino rats : Immunopathological and antimicrobial study. https://doi.org/10.1177/0394632015572075

Ranasinghe, P., Pigera, S., Premakumara, G.S., Galappaththy, P., Constantine, G.R., Katulanda, P., 2013. Medicinal properties of "true" cinnamon (Cinnamomum zeylanicum): A systematic review. BMC Complement. Altern. Med. 13. https:// doi.org/10.1186/1472-6882-13-275

Roth-Walter, F., Moskovskich, A., Gomez-Casado, C., Diaz-Perales, A., Oida, K., Singer, J., Kinaciyan, http://jurnal.unissula.ac.id/index.php/sainsmedika

T., Fuchs, H.C., Jensen-Jarolim, E., 2014. Immune Suppressive Effect of Cinnamaldehyde Due to Inhibition of Proliferation and Induction of Apoptosis in Immune Cells: Implications in Cancer. PLoS One 9, e108402.

Sproston, N.R., Ashworth, J.J., 2018. Role of Creactive protein at sites of inflammation and infection. Front. Immunol. 9, 1-11. https://doi. org/10.3389/fimmu.2018.00754

Tong, S.Y.C., Davis, J.S., Eichenberger, E., Holland, T.L., Fowler Jr, V.G., 2015. Staphylococcus aureus infections: epidemiology, pathophysiology, clinical manifestations, and management. Clin. Microbiol. Rev. 28, 603-661. https://doi. org/10.1128/CMR.00134-14

Vallianou, N., Tsang, C., Taghizadeh, M., Davoodvandi, A., Jafarnejad, S., 2019. Effect of cinnamon (Cinnamomum Zeylanicum) supplementation on serum C-reactive protein concentrations: A meta-analysis and systematic review. Complement. Ther. Med. 42, 271-278. https:// doi.org/10.1016/j.ctim.2018.12.005

Vetal, S., Bodhankar, S.L., Mohan, V., Thakurdesai, P.A., 2013. Anti-inflammatory and anti-arthritic activity of type-A procyanidine polyphenols from bark of Cinnamomum zeylanicum in rats. Food Sci. Hum. Wellness 2, 59-67. https://doi. org/10.1016/j.fshw.2013.03.003

Wardatun, S., Rustiani, E., Alfiani, N., Rissani, D., 2017. Study Effect Type of Extraction Method and Type solvent to cinnamaldehyde and trans-cinnamic acid dry extract cinnamon (Cinnamomum burmanii [Nees \& T, Nees]Blume). J. Young Pharm. 9, S1-S4. https://doi.org/10.5530/ jyp. 2017

Yu, W., Yao, D., Yu, S., Wang, X., Li, X., Wang, M., Liu, S., Feng, Z., Chen, X., Li, W., Wang, L., Liu, W., Ma, J., Yu, L., Tong, C., Song, B., Cui, Y., 2018. Protective humoral and CD $4+\mathrm{T}$ cellular immune responses of Staphylococcus aureus vaccine $\mathrm{MntC}$ in a murine peritonitis model. Sci. Rep. 8, 1-13. https://doi.org/10.1038/s41598018-22044-y 